\title{
TRANSFORMATION OF STATE GOVERNMENT IN UKRAINE
}

The article discusses the principles of organization, functioning and interaction of the system of central executive bodies and local authorities, models of the distribution of powers and responsibilities between them. Attention is drawn to the essence of such interaction and the connection of these bodies with other facts and processes of public and state life is manifested.

The search for ways to improve the legislation of Ukraine, in accordance with the standards of the Council of Europe, in the context of decentralization and local government reform, has been carried out. In particular, attention is drawn to problematic issues related to the fact that the citizens of Ukraine getting their own administrative centers with clearly defined territories can simultaneously destroy the decentralization reform, concentrating all the powers in the hands of the central government.

In this regard, the issue of establishing territories of territorial communities cannot be the authority of a centralized executive power, that is, the Cabinet of Ministers of Ukraine. It should be determined by the legislative body - the Verkhovna Rada of Ukraine jointly with the local self-government bodies. Further re-organization of local state administrations into prefectural bodies, which will oversee the legality of certain community decisions, also needs in-depth analysis.

The spheres of activity of the state are directly transformed into the spheres of public administration. Recognizing the leading idea of the self-government's study, the authors do not negate the concept of "public administration". The article proves that it is the democratic transformation of public administration that will enable modern local self-government institutions to be formed.

In this context, the powers of local governments and executive authorities in their interaction are analyzed in detail. The powers are delegated by the state to local self-government bodies only at the level of the administrative-territorial structure at which it is possible and appropriate to exercise them. And legal acts of local governments, adopted in violation of the Constitution and legislation of Ukraine, must be stopped until the question of their legality is resolved.

Key words: self-government, management, administrative center, local community, Constitution of Ukraine. 


\section{Diana Kirika,}

Head of the Department

of Theoretical, Legal

and Social Humanities

of the State Agrarian

and Engineering University

in Podilya,

Doctor of Law, Associate

Professor

orcid.org/0000-0002-3633-0103

dkirika7@gmail.com

\section{Alla Bodnar,}

Assistant

at the Department

of Theoretical and Social

and Humanities

of the State Agrarian

and Engineering University

in Podilya,

Candidate of Historical

Sciences

orcid.org/0000-0001-6725-3625

bodnar.alla@ukr.net

\author{
In spite of a certain "autonomy", the interest \\ of the municipal authorities is still part \\ of the general social interest realized \\ within the state. \\ M. Baimuratov
}

Introduction, purpose, objectives, methodology

One of the most important problems in Ukraine today is the organization of state power, comprehending new approaches to understand the distinction between state and local government. Currently, the constitutional consolidation of the principles of organization and functioning of the central executive power system is being pursued in order to optimize and improve the efficiency of work, define the distribution model of powers and responsibilities, particular in the context of decentralization and local self-government reform.

The citizens of Ukraine are rather pessimistic about the current, largely corrupt, political elite and authorities of all levels. Today, the resources to change the existing model of government are exhausted. In particular, the current system of government is unable to ensure the irreversible nature of the democratic transformation process, demonstrates its limitations in ability to prevent conflicts that unbalance the political system. Therefore, the best way out of this situation is to pursue a course of constitutional reform that would clearly balance the role and functions of different authorities (Kirika, 2016).

Democratic countries put into practice a certain set of principles: the distribution of power functions, the system of "containment and counterweights", popular control over government, people's participation in government, etc.

As the aim of Ukrainian policy is to move away from a centralized model of government in the country, ensuring the capacity of local self-government and building an effective territorial organization system of power in Ukraine (Postanovi VRU, 2015), the purpose of this study is, first of all, searching for improvement of legislative regulation, in accordance with Council of Europe standards, relations of executive and local self-government bodies with citizens and economic entities, increasing the efficiency of the administrative (non-judicial) appeal procedure (law on administrative procedure). 
The issue of interaction between public authorities and citizens' associations has been studied at various times by many scientists, in particular, Bogasheva I.V., Vashchuk O.M., Vihlyaev M.Y., Avakyan S.A., Darkov A.A., Erzhov O.V., Yuryev S.S., Shudko D.V. and others. The goal of our study is to address the issue of the interaction principles between public authorities and local self-government, which remains insufficient, so it is important to pay attention to the essence of the principles interaction and to identify their connection with other facts and processes of public and state life.

In our opinion, in order to understand the question of the boundary between state and local government, it is necessary to analyze whether the community has separate, non-state power; whether local self-government is part of the state mechanism, or whether it is a separate subject of power relations in society (Wojciechowski, 2016).

Novelties of modern Ukrainian legislation

Today, a number of common questions arise before scientists: what is the state in general? What is the essence of state and local self-government? What kind of boundary between them and how they participate?

In the light of recent changes, namely, consideration of Draft Law No. 2653 on amendments to the Law of Ukraine "On Local Self-Government in Ukraine" (Zakon Ukrayini No. 24, 1997) of 04.16.2020, it is planned to:

1) introduce the concept of the administrative center of the territorial community and the territory of the territorial community.

2) before the adoption of the Law on the Administrative and Territorial Structure of Ukraine, to authorize the Cabinet of Ministers of Ukraine (hereinafter CMU) to designate administrative centers and territories of territorial communities, as well as to submit to the Verkhovna Rada of Ukraine (hereinafter VRU) draft legislative acts on the formation and liquidation of districts 5 (e-resource).

On one hand, the law decided to make it possible for the community to inform its centers and to clearly identify their persons separately. On other hand, such mechanism, according to some politicians and scholars, will destroy the decentralization reform, concentrating all powers in the central government hands.

It is envisaged that the administrative center of the UTC will be a settlement (village, town, city) with developed infrastructure and, as a rule, located closest to the geographical center of the community territory in which the representative body of local self-government is located. In addition, it is recorded that in 2020, the first local deputy elections of village, town, city councils and proper village, town, city heads of territorial communities, which territories are approved by the CMU on the basis of this law, has to be held at the same time as regular local elections in 2020.

What are the "pros" and "cons" of such changes? Each authority must act solely on the basis of the highest legal force and the laws and regulations. This is one of the basic principles of local self-government, which is mentioned in Article 4 of the Law of Ukraine "On Local Self-Government in Ukraine", namely: Local self-government in Ukraine is carried out on the principles of legality, rights, organizational and financial 
independence within the powers defined by this and other laws (Zakon Ukrayini No. 24, 1997). In other words, the basis for all actions of a local government body should be specific laws and by-laws whose task is to detail the effect of the law.

Certainly, the first and main document on which local self-government is based is the XI section of the Constitution of Ukraine (Konstitutsiya Ukrayini Osnovniy Zakon, 1996). The following important documents are two special laws: "On Local Self-Government in Ukraine", which outlines the system, legal status, mechanics of interaction of local self-government bodies in Ukraine, and "On the status of deputies of local councils" (Zakon Ukrayini No. 40, 2002), which is relating to members of local councils and outlines the legal status, boundaries and guarantees of their activities.

How do the newly adopted changes compare with the current legislation of Ukraine and why have they caused new resonance in society?

The key problem of the draft law No. 2653 on amending the Law of Ukraine "On Local Self-Government in Ukraine" is that the CMU is temporary powers granted (until the adoption of a new law on the administrative and territorial structure), the authority to approve territories of territorial communities. And this is contrary to Article 2 and Article 92 of the Constitution of Ukraine, under which the territorial structure and boundaries of territorial communities are established exclusively by the laws of Ukraine. Instead, the Constitution of Ukraine recognizes the right of the territorial community and local governments to independently resolve issues of local importance within the laws of Ukraine. The same provision is in line with Article 4, Part 2, of the European Charter of Local Self-Government.

Based on the above, the issue of territorial community territories cannot be the responsibility of a centralized executive power, that is, the CMU. It should be determined by the VRU together with the local authorities.

\section{Powers of local self-government bodies, executive authorities and their interaction}

In accordance to Part 3 of Article 143 of the Constitution of Ukraine, local selfgovernment bodies maybeempoweredby law with separatepowers of executivebodies. In theirturn, local councils can delegate some of their powers to regional and district state administrations and monitor the exercise of these powers. The Local Self-Government law contains a list of eighty powers and about seventy of them with respect to local self-government bodies.

Having defined the leading idea of self-government, the concept of "public administration" should not be negated. It's democratic transformation that gave rise to modern local self-government institutions. Content management is the realization process of state power, its external, materialized expression, which does not exist outside it. The spheres of state activity are directly transformed into the spheres of public administration. This is the development and implementation of domestic and foreign policy, the legal definition and regulation of relations throughout the society, the formation and implementation of the state budget (Derzhavne upravlinnya, 2012). 
One of the principles of local self-government is the combination of local and state interests in (Sakhno, 2013). According to the Concept of Reforming Local SelfGovernment and Territorial Organization of Government in Ukraine, it is quite possible to achieve optimal distribution of powers between local self-government bodies and executive authorities. The accessibility and proper quality of public services that is ensured through the optimal distribution of powers between local and executive authorities at different levels of administrative and territorial organization, based on the principles of subsidiarity and decentralization. Basic-level local governments are empowered in accordance with their staffing, financial, infrastructural potential and resources on a new territorial basis (Rozporyadzhennya KMU 2014).

The main powers of the local self-government bodies on basic level are to provide: local economic development; development of local infrastructure; community development planning; solving the issues of territory development; improvement of the territory; provision of housing and communal services; organization of passenger transportation on the community territory; maintenance of streets and roads in settlements; public safety; extinguishing fires; management of secondary, pre-school and extracurricular education institutions; provision of ambulance services; development of culture and physical culture; providing social assistance through territorial centers. Structural territorial bodies subdivisions of central executive bodies at the basic level will provide services in: sanitary and epidemiological protection; social protection of the population; treasury service; registration of civil acts.

The main powers of the local self-government bodies on district level are to provide: education and training of children in boarding schools of general profile; provision of secondary level medical services.

The main powers of the local self-government bodies on regional level are to provide: regional development; environmental protection; development of regional infrastructure, first of all regional highways, network of interregional and interregional public transport routes; vocational education; providing highly specialized medical care; development of culture, tourism (Rozporyadzhennya KMU, 2014).

The powers are delegated by the state to local self-government bodies operating at the level of the administrative and territorial structure at which it is possible and appropriate to exercise them in view of human, financial and infrastructural potential.

For the optimal distribution of powers between local and executive authorities at different levels of administrative and territorial structure, it is necessary to ensure:

- system improvement of public involvement in the development of management decisions and control over their implementation;

- defining a sufficient tax base to enable local self-government bodies to exercise their authority;

- formation of representative bodies of local self-government with their own executive bodies; 
- effective state control over the observance of local self-government bodies by the requirements of the Constitution and laws of Ukraine (Rozporyadzhennya KMU, 2014).

At the same time, if we analyze the current legislation of Ukraine, it becomes clear that the local governments exercise a number of powers that are inherent in state authorities. Firstly, this is due to the possibility of the state authorities delegating their powers to local governments, and secondly, to delegating part of their powers to local governments.

Performing such powers, local governments act as subjects of administrative law. It should be noted that the ratio of state and local administration as elements of public administration in administrative-territorial units depends on the level of administrative-territorial units: the higher it is, the less local government and the more public administration, and vice versa. At the national level, the interests of local self-government are not directly represented at all, since the suggestion to create a bicameral parliament where the second chamber should be composed of representatives of the regions was not supported. Conversely, at the lower administrative and territorial levels - a village, a town, a city - the state is not represented by its administrative bodies - local state administrations, and the full power of the authorities in these territories belongs to the local self-government bodies (Hladiy, 2016...).

On the issues of exercising the powers of executive bodies, local self-government bodies are under control of the respective executive authorities. Legal acts of local self-government bodies adopted in violation of the Constitution and legislation of Ukraine may be suspended pending the resolution of their legality in court. The damage caused as a result of wrong decisions, actions of local self-government bodies, they are fully compensated by their own funds.

According to the Law of Ukraine "On Local Self-Government in Ukraine", the powers of the local council may be terminated prematurely by the decision of the local referendum if the council passed a decision in violation of the Constitution and other laws of Ukraine. Local self-government is closely linked to government and has both commonalities and distinctive features.

In the light of current law-making processes, it is necessary to pay attention to the changes proposed by the higher bodies of the legislative and executive branches of power in Ukraine. First of all, it is related to the reform of state bodies of the executive power provided by the Plan of legislative support of reforms in Ukraine. The reform of the Cabinet of Ministers and the system of other state bodies provide:

- amendments to the Law of Ukraine "On the Cabinet of Ministers of Ukraine" and other legislative acts on: consolidation of the general principles of the decisionmaking process by the Cabinet of Ministers of Ukraine; introduction of collegiality and transparency of its activities, in particular through early publication of draft governmental decisions; optimizing the composition and staffing of the Cabinet of Ministers of Ukraine; increased responsibility; 
- amendments to the Law of Ukraine "On Central Executive Bodies" and other legislative acts concerning: introduction of the Institute of State Secretaries of Ministries; reduction of political positions of Deputy Ministers; reorganization of departments of ministries, formation of typical secretariats of ministries and other central executive bodies; optimization of ministries financing and other central executive bodies; granting to the Minister exclusive powers submitting proposals to the Cabinet of Ministers of Ukraine on the appointment of their deputies and heads of the central executive bodies, which are in its coordination, strengthening its responsibility for the implementation of state policy in the relevant sphere; providing the head of the central executive authority with the authority to appoint his / her deputies (Postanovi VRU, 2015).

\section{Local prefectural state administrations}

Creating wealthy communities is not the only part of decentralization reform. In the future, it was planned to redeploy local state administrations into prefecturaltype bodies, which would oversee the legality of certain community decisions, and to give the executive functions of the RSA and the DSA, which they own, to the executive committees of district and oblast councils. In this regard, the Draft Amendments to the Constitution of Ukraine (concerning decentralization of power) No. 2217 of July 1, 2015, were developed and implemented by the Institute of Prefecture. In this document, the implementation of the executive power in the regions and districts, in Kiev and Sevastopol relied on the prefect. The prefect is appointed and dismissed by the President of Ukraine at the request of the CMU. Prefect is a civil servant who, in the exercise of his / her powers, is accountable to the President, accountable to and under the control of the CMU (Proekt zmin do Konstitutsiyi Ukrayini No. 2217, 2015).

However, the above-mentioned Draft is currently withdrawn by Law No. 2598 of December 13, 2019 for consideration by the Verkhovna Rada of Ukraine, which establishes direct presidential interference with local self-government and completely contradicts the concept of "decentralization". The "prefect" post, in particular, is considered to be key in destroying decentralization reform.

Let's try to analyze the prefect's powers proposed in the Draft Amendments to the Constitution of Ukraine (on decentralization of power) No. 2217 of 07.01.15, with modern interpretation.

Prefect in the relevant territory:

1) supervises the observance of the Constitution and laws of Ukraine by local self-government bodies and coordinates the activities of territorial bodies of central executive bodies;

2) ensures implementation of state programs;

3) directs and organizes the territorial bodies activities of the central executive authorities and ensures their interaction with the local self-government bodies in the event of martial law, state of emergency or situation;

4) exercise other powers as defined by the Constitution and laws of Ukraine (Proekt zmin do Konstitutsiyi Ukrayini No. 2217, 2015). 
The prefect, on the basis and in the manner prescribed by law, issues acts that are binding in the relevant territory. The prefect's acts may be canceled by the President of Ukraine or the Cabinet of Ministers of Ukraine in accordance with the procedure established by law. Instead, executive authorities of local self-government of the community, executive committees of the district, regional council in accordance with the law may be delegated some powers of executive authorities (Postanovi VRU № 509, 2015). The state finances the exercise of these powers in full at the expense of the State Budget of Ukraine, and transfers to the local self-government bodies the relevant objects of state ownership.

What exactly prompted the authorities to withdraw the Draft Amendments to the Constitution of Ukraine (concerning decentralization of power) No. 2217 of 07.01.15. According to the draft, the prefect is appointed and recalled only by the president, and the prefect has the right to completely nullify any decision made by the community for his own good. It is worth noting that the Verkhovna Rada Committee on the Organization of State Power, Local Self-Government, Regional Development and Urban Development did not support the draft amendments to the Constitution regarding decentralization and the new administrative and territorial structure. Emphasis is placed on focusing unjustifiably broad powers in the Prefect hands 13 (e-resource).

In our opinion, when distinguishing between the concepts of state power and public authorities, the second act only as a means of achieving the goals of power. The question of the separation of subject and object of power is poorly developed. This is due to the fact that power is generally regarded as a one-way process: the subject reigns and the object obeys. Analyzing this approach, we can distinguish the position that within the power paradigm, the state government pursues and realizes only its interests, which leads to its alienation from society, "isolation from the people". As a result, state power confronts itself with society and is formed as an alienated force, which sooner or later leads to its crisis, there is a deformation of its nature, its transformation into arbitrariness. In this case, the question must be asked: what will this government be without the support of society? Is it possible to exist outside the society without taking into account its interests? (Wojciechowski, 2016)

\section{Conclusions}

For Ukraine, the processes of democracy and the modernization of statehood lie in the plane of seeking a balance of centralization and decentralization. The effectiveness of these processes is directly related to the effectiveness of public authority, the rationality of its systemic-structural organization, methods and forms of implementation at different levels of this organization, the optimality of distribution of powers between the state and municipal authorities, the balanced use of mechanisms of control and accountability of local authorities, self-government (Sluzhbove pravo monograph, 2017).

Obstacles to the successful implementation of administrative-territorial reform remains: significant dependence of territories from the center; personnel and financial 
weakness of communities; rural degradation; low quality of public services; high level of corruption; inefficiency of management decisions. Unfortunately, there is no common vision of standardizing the powers and their resources of local governments at all levels.

In our opinion, the problem lies in the fact that Ukraine is following the path of making partial amendments to existing regulations. This path only slows down the reform process. It is urgent to adopt completely new laws on self-government, which would enshrine the principles of delimitation of powers of the state and administrative-territorial units with the appropriate transfer of powers. It is on this basis that it is possible to consolidate measures to ensure the smooth operation of all actors at the basic and subregional levels.

We offer to recognize the basic principle of the exclusive competence of the community council. It is on this principle that the community within the law will have the right to freely decide any issue that is not excluded from the scope of its competence and does not belong to the competence of any other body. The law must clearly state the list of the community's own powers, which would be exercised exclusively by it and no body would have the right to interfere in its activities. Such sectoral powers include, first of all: local taxes and fees; the share of national taxes assigned to local budgets; transfer of direct transfers to local budgets.

But it is impossible to first adopt all the laws and then proceed to their implementation. First of all, it is necessary to build a platform on which the state will be based, namely, the primary part of the community, which receives authority and takes responsibility. Further, the mechanism of self-government should be extended to the level of districts and regional centers, where executive committees and prefectures should be established. In this way it is possible to strengthen the executive mechanism of local self-government. Only the direct democratic participation of citizens in governance at the national, regional and local levels, the exercise by the people of their sovereign power will contribute to the full interaction of government and society.

\section{Bibliography:}

1. Войцеховський Н.В. Правова природа меж державної влади та влади місцевого самоврядування. Антропосоціокультурна природа права : матеріали наукової конференції (Чернівці, 25-27 травня 2016р.). - Чернівці : ЧНУ, 2016. 544 с.

2. Гладій В. І. Місцеве самоврядування як ресурс політики євроінтеграції : досвід Вишеградської групи та перспективи України : дис. кандидата політ. наук ДВНЗ «Прикарпатський Національний університет імені Василя Стефаника». 2020. 238 с.

3. Державне управління : підручник : у 2 т. Нац. акад. держ. упр. при Президентові України / ред. кол. : Ю. В. Ковбасюк, К. О. Ващенко, Ю. П. Сурмін та ін. К., Дніпропетровськ : НАДУ, 2012. Т. 1. 564 с.

4. Закон України «Про місцеве самоврядування в Україні» / Відомості Верховної Ради Украӥни, 1997, № 24, ст. 170 (Редакція від 02.04.2020, підстава - 540-IX)'1'

5. Закон України «Про статус депутатів місцевих рад» / Відомості Верховної Ради України (ВВР), 2002, № 40, ст. 290 (Редакція від 20.03.2020, підстава - 524-ІХ) 
6. Конституція України (Основний Закон) / Відомості Верховної Ради України. 1996. № 30.

7. Концепція реформування місцевого самоврядування та територіальної організації влади в Україні / Розпорядження КМУ від 1 квітня 2014 р. № 333-р.

8. Кіріка Д.В. Спонтанний вплив децентралізації на правосвідомість громадянського суспільства. Антропосоиіокультурна природа права : матеріали наукової конференції (Чернівці, 25-27 травня 2016 р.). Чернівці : ЧНУ, 2016. 544 с.

9. Постанови ВРУ «Про План законодавчого забезпечення реформ в Україні» № 509-VIII від 04.06.2015 р. / Відомості Верховної Ради України, 2015, № 31, ст. 297.

10. Проект змін до Конституції України (щодо децентралізації влади) № 2217 від 01.07.15.

11. Проект закону № 2653 про внесення змін до Закону України «Про місцеве самоврядування в Україні» URL: https:/www.unn.com.ua/uk/news/1864190-rada-ukhalila-vtsilomu-zakonoproekt-pro-mistseve-samovryaduvannya (дата звернення16.04.2020 p.)

12. Проект Закону про внесення змін до Конституції України (щодо децентралізації влади)» URL: https://petition.president.gov.ua/petition/81494 (дата звернення 24.12.2019.)

13. Сахно В.О. До питання утворення та діяльності місцевих державних адміністрацій в Україні. Публічне право. № 3 (11). 2013. С. 68.

14. Службове право: витоки, сучасність та перспективи розвитку : колективна монографія / за заг. ред. Т.О. Коломоєць, В.К. Колпакова. Запоріжжя : Видавничий дім «Гельветика», 2017. 328 с.

\section{References:}

1. Wojciechowski N. V. (2016) Pravova priroda mezh derzhavnoyi vladi ta vladi mistsevogo samovryaduvannya [The legal nature of the boundaries of state and local government]. Antroposotsiokulturna priroda prava: materiali naukovoyi konferentsiyi-Anthroposocyocultural nature of law : materials of scientific conference (Chernivtsi, 25-27 travnya 2016 r.). Chernivtsi : ChNU, 2016. 544 p. [in Ukrainian].

2. Hladiy V.I. (2020) Mistseve samovryaduvannya yak resurs politiki Evrointegratsiyi : dosvid Vishegradskoyi grupi ta perspektivi Ukrayini [Local self-government as a resource for European integration policy : experience of the Visegrad Group and prospects of Ukraine]. Candidate's thesis DVNZ «Prikarpatskiy Natsionalniy universitet imeni Vasilya Stefanika». 238 s. [in Ukrainian].

3. Kovbasyuk Y. V. (Eds.). (2012) Derzhavne upravlinnya : u 2 t. [Public administration: in 2 volumes] / Nats. akad. derzh. upr. pri Prezidentovi Ukrayini ; [red. kol. : Y. V. Kovbasyuk, K. O. Vaschenko, Y. P. Surmin ta in.]. K., Dnipropetrovsk : NADU, 2012. Vol. 1. 564 p. [in Ukrainian].

4. Zakon Ukrayini (2020) «Pro mistseve samovryaduvannya v Ukrayini» [Law of Ukraine «On Local Self-Government in Ukraine»] : Vidomosti Verhovnoyi Radi Ukrayini, 1997, № 24, st. 170 (Redaktsiya vid 02.04.2020, pidstava 540-IX) [in Ukrainian].

5. Zakon Ukrayini (2020) «Pro status deputativ mistsevih rad» [Law of Ukraine «On the status of deputies of local councils»] : Vidomosti Verhovnoyi Radi Ukrayini (VVR), 2002, № 40, st. 290 (Redaktsiya vid 20.03.2020, pidstava 524-IX) [in Ukrainian].

6. Konstitutsiya Ukrayini (1996). (Osnovniy Zakon) [The Constitution of Ukraine (Main Law)] : Vidomosti Verhovnoyi Radi Ukrayini. 1996. № 30. [in Ukrainian].

7. Kontseptsiya reformuvannya mistsevogo samovryaduvannya ta teritorialnoyi organizatsiyi vladi v Ukrayini (2014) [Concept of reforming local self-government and territorial organization of government in Ukraine] / Rozporyadzhennya KMU vid 1 kvitnya 2014 r. № 333-r. [in Ukrainian]. 
8. Kirika D. (2016). Spontanniy vpliv detsentralizatsiyi na pravosvidomist gromadyanskogo susplistva [The Spontaneous Impact of Decentralization on Civil Society Consciousness]. Antroposotsiokulturna priroda prava: materiali naukovoyi konferentsiyi-Anthroposocyocultural nature of law : materials of scientific conference (Chernivtsi, 25-27 travnya 2016r.). Chernivtsi : ChNU, 2016. 544 p. [in Ukrainian].

9. Postanovi VRU (2015). «Pro Plan zakonodavchogo zabezpechennya reform v Ukrayini» № 509-VIII vid 04.06.2015 r. [Resolutions of VRU “On Plan for Legislative Support to Reforms in Ukraine”, No. 509-VIII of 06.04.2015] / Vidomosti Verhovnoyi Radi Ukrayini, 2015, № 31, st. 297. [in Ukrainian].

10. Proekt zmin do Konstitutsiyi Ukrayini ( schodo detsentralizatsiyi vladi ) [Draft amendments to the Constitution of Ukraine (on decentralization of power)] № 2217 vid 01.07.15. [in Ukrainian].

11. Proekt zakonu № 2653 pro vnesennya zmin do Zakonu Ukraine «Pro mischeve samovryaduvannya v Ukrainy» [Draft Law No. 2653 on Amendments to the Law of Ukraine "On Local Self-Government in Ukraine"]. URL: https://www.unn.com.ua/uk/news/1864190rada-ukhalila-v-tsilomu-zakonoproekt-pro-mistseve-samovryaduvannya [in Ukrainian].

12. Proekt Zakonu pro vnesennia zmin do Konstytutsii Ukrainy (shchodo detsentralizatsii vlady)» [Draft Law on Amendments to the Constitution of Ukraine (regarding decentralization of power)]. URL: https://petition.president.gov.ua/petition/81494 [in Ukrainian].

13. Sakhno V. O. Do pitannya utvorennya ta diyalnosti mistsevih derzhavnih administratsiy $\mathrm{v}$ Ukrayini [On the question of formation and activity of local state administrations in Ukraine] : Publichne pravo. Public law. № 3 (11)/2013, S. 68. [in Ukrainian].

14. Kolomoets T. O., Kolpakova V. K. (2017) Sluzhbove pravo: vitoki, suchasnist ta perspektivi rozvitku [Service law: origins, present and development prospects] kolektivna monografiya Zaporizhzhia : Vidavnichiy dim «Gelvetika», 2017. 328 s. [in Ukrainian].

\title{
ТРАНСФОРМАЦІї ДЕРЖАВНОЇ ВЛАДИ В УКРАЇНІ
}

\author{
Діана Кіріка, \\ завідувач кафедри теоретико-правових і соціально-гуманітарних дисциплін \\ Подільського державного аграрно-технічного університету, \\ кандидат юридичних наук, доцент \\ orcid.org/0000-0002-3633-0103 \\ dkirika7@gmail.com

\section{Алла Боднар,} \\ асистент кафедри теоретико-правових і соціально-гуманітарних дисциплін \\ Подільського державного аграрно-технічного університету, \\ кандидат історичних наук \\ orcid.org/0000-0001-6725-3625 \\ bodnar.alla@ukr.net
}

У статті розглядаються засади організації, функиіонування та взаємодії системи центральних органів виконавчої влади та органів місчевого самоврядування, моделі розподілу між ними повноважень та відповідальності. Звертається увага на сутність такої взаємодії та виявлясться зв'язок ичих органів з іншими фактами і процесами суспільного та державного життя. 
Здійснено пошук иляхів удосконалення законодавства України відповідно до стандартів Ради Європи, в контексті децентралізації та реформи місиевого самоврядування. А саме звертається увага на проблемні питання, пов'язані з тим, що отримання громадянами України власних адміністративних центрів із чітко окресленими територіями може паралельно знищити реформу децентралізащії, сконщентрувавщи всі повноваження в руках центральної влади.

Доводиться, щуо питання встановлення територій територіальних громад не може бути повноваженням иентралізованої виконавчої влади, тобто Кабінету Міністрів України. Воно має визначатися законодавчим органом влади - Верховною Радою Украӥни спільно з органами місчевого самоврядування. Перепрофілювання в подальшому місиевих державних адміністрацій в органи префектурного типу, які наглядатимуть за законністю тих чи інших рішень громад, також потребуе глибокого аналізу.

Сфери діяльності держави безпосередньо трансформуються у сфери державного управління. Визнавши провідною ідею дослідження самоврядність, автори не нівелюють поняття «державного управління». У статті доводиться, що саме демократична трансформація державного управління дасть можливість сформуватися сучасним інститутам місиевого самоврядування.

У иььомуконтексті детально аналізуються повноваження органівмісцевого самоврядування та органів виконавчої влади в їх взаємодії. Повноваження передаються державою органам місиевого самоврядування тільки на тому рівні адміністративно-територіального устрою, на якому їм можливо і доцільно їх здійснювати. А правові акти органів місиевого самоврядування, прийняті з порушенням Конституції та законодавства Украӥни, повинні бути зупинені до розв'язання питання про їх законність.

Ключові слова: самоврядування, управління, адміністративний центр, територіальна громада, Конституція України. 